Review

\title{
The Structural Characteristics of Seaweed Polysaccharides and Their Application in Gel Drug Delivery Systems
}

\author{
Haowei Zhong ${ }^{\dagger}$, Xiaoran Gao ${ }^{\dagger}$, Cui Cheng *(D), Chun Liu, Qiaowen Wang and Xiao Han * \\ College of Biological Science and Engineering, Fuzhou University, Fuzhou 350108, China; \\ N195720010@fzu.edu.cn (H.Z.); N185720009@fzu.edu.cn (X.G.); ibptlc@fzu.edu.cn (C.L.); \\ wangqiaowen8@163.com (Q.W.) \\ * Correspondence: ibptcc@fzu.edu.cn (C.C.); hanxiao@fzu.edu.cn (X.H.) \\ + These authors contributed equally to this work.
}

Received: 27 November 2020; Accepted: 17 December 2020; Published: 21 December 2020

\begin{abstract}
In recent years, researchers across various fields have shown a keen interest in the exploitation of biocompatible natural polymer materials, especially the development and application of seaweed polysaccharides. Seaweed polysaccharides are a multi-component mixture composed of one or more monosaccharides, which have the functions of being anti-virus, anti-tumor, anti-mutation, anti-radiation and enhancing immunity. These biological activities allow them to be applied in various controllable and sustained anti-inflammatory and anticancer drug delivery systems, such as seaweed polysaccharide-based nanoparticles, microspheres and gels, etc. This review summarizes the advantages of alginic acid, carrageenan and other seaweed polysaccharides, and focuses on their application in gel drug delivery systems (such as nanogels, microgels and hydrogels). In addition, recent literature reports and applications of seaweed polysaccharides are also discussed.
\end{abstract}

Keywords: alginic acid; carrageenan; seaweed polysaccharides; gels; drug delivery

\section{Introduction}

Marine plants are mainly lower algae plants, higher plants and seed plants. Based on their pigment, cell structure, reproductive method and reproductive organ structure, we generally divide marine algae plants into: Cyanophyta, Chlorophyta, Xanthophyta, Euglenophyta, Pyrrophyta, Chrysophyta, Charophyta, Rhodophyta, Bacillariophyta and Phaeophyta. Among these, Rhodophyta, Phaeophyta and Chlorophyta are the most widely used in biomaterials. With the recent development and progress in scientific research, polysaccharides, polyphenols, amino acids, polyunsaturated fatty acids, terpenes and other bioactive components have been isolated from seaweed. These compounds exhibit excellent anti-inflammatory, antioxidant, bacteriostatic, anticancer and anticoagulant effects [1-6], which makes the use of algae in food, medical and other fields increasingly prominent.

In the utilization of algae resources, algae polysaccharides are an extremely important component. Algae polysaccharides are a multi-component mixture composed of one or more monosaccharides, which are connected with 1, 3 and 1, 4 glycosidic bonds, distributed between and within the algae cells. They are generally water-soluble, and some contain sulfate groups, which provide high viscosity or solidification properties. There are many types of seaweed polysaccharides that arise from different sources, which are divided into Rhodophyta polysaccharides, Fucophyta polysaccharides, Chlorophyta polysaccharides, etc. [2]. The main types of algae and their products are shown in Figure 1. 


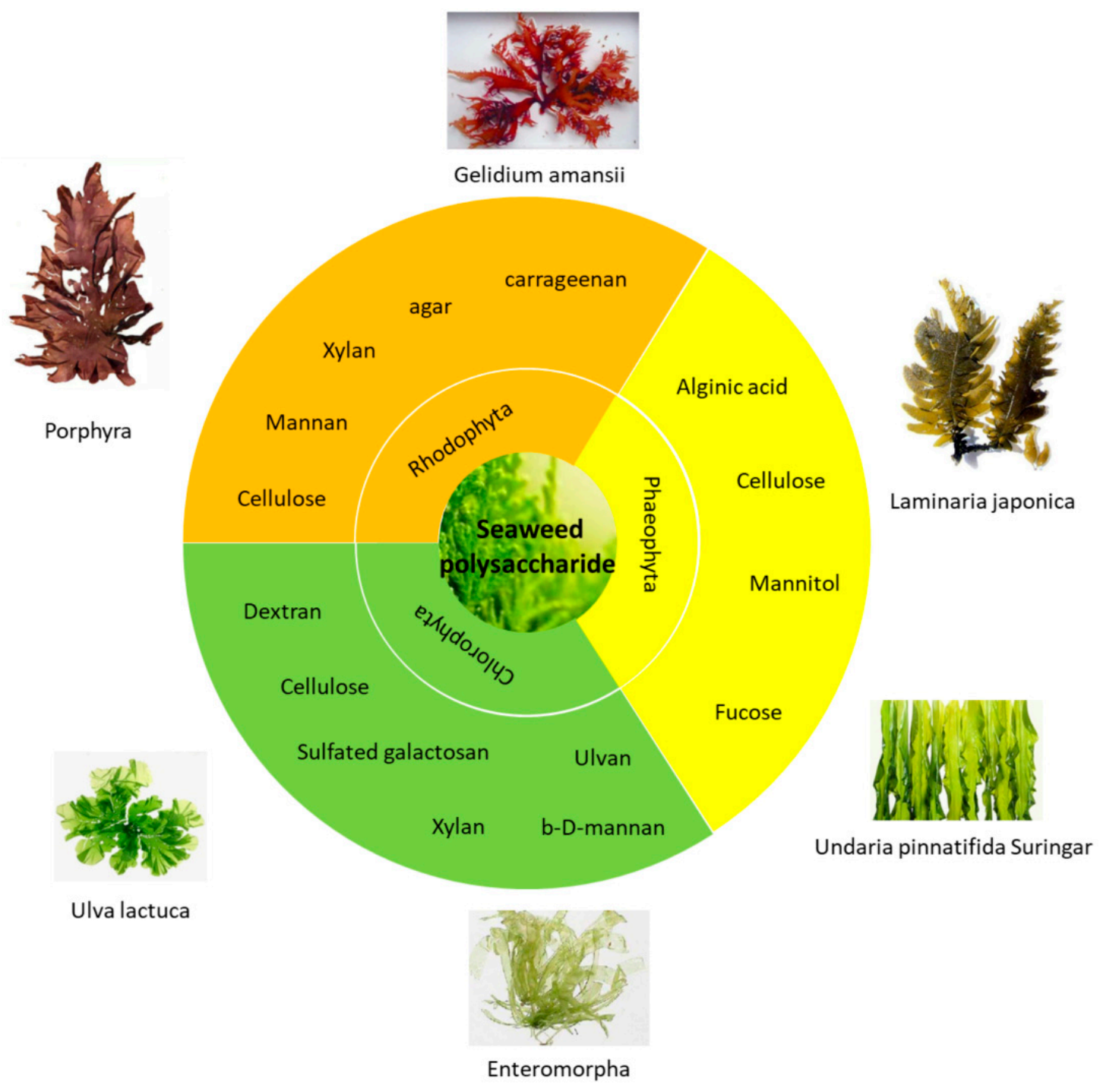

Figure 1. Classification of the main seaweed polysaccharides and their sources.

In recent years, more in-depth research on the medicinal value of algae polysaccharides has been conducted, which has attempted to establish the mechanism behind the medicinal functions of algae polysaccharides both in vivo and in vitro, as well as promoted the development and utilization of algae polysaccharides in pharmaceutical preparations. Wang [7] reported that seaweed polysaccharides have good inhibitory effects on matrix metalloproteinases (MMPs), which improves the upregulation of MMP expression caused by ultraviolet $b$ (UVB) radiation, inflammatory cytokines and certain hormones and chemical agents, as well as reducing the inflammation and degradation of connective tissue caused by free radicals and reactive oxygen species (ROS) initiating the mitogen-activated protein kinase pathway [8]. In addition, it showed a good promoting effect on reducing the damage that is induced by free radicals and ROS [9]. Other reports have summarized the potential anticancer mechanisms of algal polysaccharides, including induction of apoptosis, cell cycle arrest, regulation of transduction signal pathways, inhibition of migration and angiogenesis and activation of the immune response and antioxidant system [10-12]. They found that vascular endothelial growth factor/vascular endothelial growth factor receptor 2 (VEGF/VEGFR2), transforming growth factor $\beta$ receptor/Smad/Snail (TGFR/Smad/Snail), Toll-like receptor4/reactive oxygen species/endoplasmic reticulum (TLR4/ROS/ER), chemokines CXC ligand 12/CXC receptor 4 (CXCL12/CXCR4), TGFR/Smad7/Smurf2, phosphatidylinositol 3-kinase/protein kinase $\mathrm{B} /$ the mammalian target of rapamycin (PI3K/AKT/mTOR), PDZ-binding kinase /t-lymphokine-activated killer cell-originated protein kinase (PBK/TOPK) and $\beta$-catenin/Wnt are the main 
cellular signaling pathways that play a key role in the prevention and treatment of tumorigenesis using algal polysaccharides [12]. With the continuous development of biomedical materials, research into new types of natural materials has received the most attention. Seaweed polysaccharides have physical structural properties and natural biological activity, and they can be extensively sourced at low cost. They hold promise for further application in various controllable and sustained anti-inflammatory and anticancer drug delivery systems, such as seaweed polysaccharide-based nanoparticles, microspheres and gels, etc. Here, gel drug delivery systems (including nanogels, microgels and hydrogels) have internal cross-linked structures that can load various drugs, thereby providing a wide range of applications in the field of drug delivery.

In order to discuss the application of seaweed polysaccharides in gel drug delivery in recent years, we searched the relevant literatures of seaweed polysaccharides based gel drug delivery system in the past three years through the websites of pubmed, Google academic and school library electronic journal platform, etc. They were divided into two categories: reviews and articles. From the reviews, we summarized the properties and characteristics of polysaccharides, and traced back the valuable citations. From the articles, the studies focusing on gel drug delivery system are extracted and summarized. Through sorting out the literature information, three types of seaweed polysaccharides were selected according to the sources of polysaccharides: alginic acid and its derivatives, carrageenan and its derivatives and other seaweed polysaccharides. Hence, in this review, the structural characteristics of the above three types of seaweed polysaccharides are summarized and the latest progress in the application of seaweed polysaccharide-based gels in drug delivery systems is discussed. We aim to provide a reference for the future research and development of seaweed polysaccharides. The summary of this review is shown in Figure 2, and the details will be expanded later. 


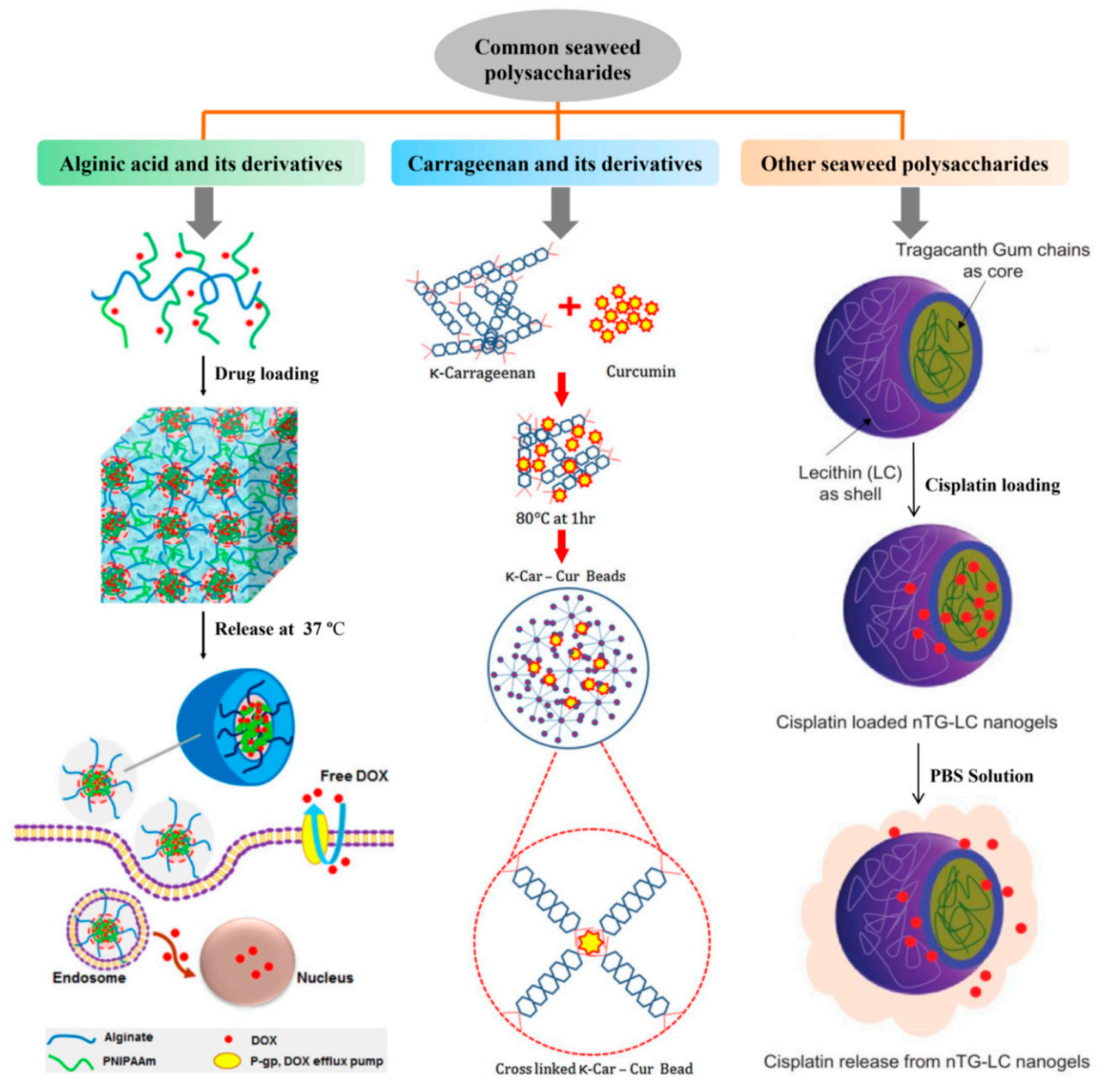

Figure 2. Structural characteristics of seaweed polysaccharides and their application in nano/micro/hydro-gel drug delivery systems.

\section{Alginic Acid and Its Derivatives}

Alginic acid, also known as acidum alginic, is essentially a straight chain block glucuronic acid, which is widely found in hundreds of brown algae, Phaeophyta. In its natural state, it combines with various cations in seawater to form various alginates, which exist in the cell wall and play a strengthening role. In the process of extraction, it can be converted into sodium, potassium, ammonium, calcium salt or other derivatives, which we call algin; commercial algin is mainly sodium alginate. As alginic acid and its derivatives have good stability, solubility and viscosity and are safe, they are often used as excipients for food or pharmaceutical preparations to achieve thickening, stability and emulsification [13]. However, recent studies have shown that alginic acid and its derivatives also have good biocompatibility, antioxidant activity and anti-inflammatory activity [14-17]. At present, they are mostly commonly applied in cosmetics, and there are various anti-wrinkle, moisturizing and anti-ultraviolet products available [6]. Application in drug delivery systems is recent and demonstrates considerable application potential, which will drive the direction of future development. 


\subsection{Structure and Characteristics}

The alginic acid product is a white to yellowish brown powder, the average molecular weight is approximately 240,000 , and its melting point is above $300{ }^{\circ} \mathrm{C}$. Insoluble in cold water and organic solvents, slightly soluble in hot water, its aqueous solution viscosity is approximately five times that of starch. It is resistant to acid, but decarboxylation occurs when it is reacted with concentrated hydrochloric acid. It exhibits selective adsorption effects towards metal ions [16], in particular, Fe (II) ions [18,19].

From a structural point of view, alginic acid is a copolymer composed of $\beta$-D-manuronic acid (mannuronate, M) and amurl guronic acid (guluronate, G) connected with $\beta-1,4$ glycosidic bonds and randomly arranged into poly-GG, poly-MG and poly-MM fragments [20], as shown in Figure 3. The linear polymers contain carboxyl groups in each uronic acid unit, and exhibit clear pH sensitivity [21]. When alginic acid is in the alkali metal salt and ammonium salt state, the solution is neutral or alkaline, and at the same time a high proportion of carboxylate groups $\left(-\mathrm{COO}^{-}\right)$result in polyanion electrolyte properties, meaning the aqueous solution has certain adhesion properties. When the $\mathrm{pH}$ value increases, the carboxylic acid group $(-\mathrm{COOH})$ continuously dissociates, the molecular chain extends and the solubility increases. However, under acidic conditions, the conversion of $-\mathrm{COO}^{-}$to $-\mathrm{COOH}$ is not as facile, the solubility decreases and the molecular chain shrinks. Below pH 3, the alginic acid solution is converted into insoluble alginic acid gel or a precipitate, which is accelerated by the addition of multivalent metal ions (such as calcium chloride) [22].

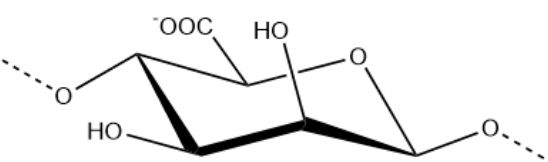

$\beta$-D-mannuronic acid ester (M)

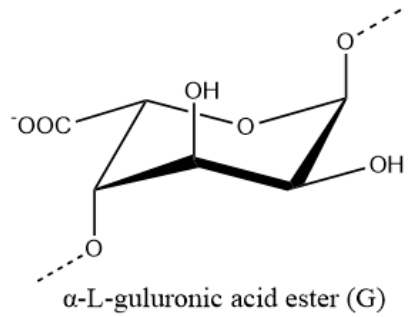

$\alpha$-L-guluronic acid ester (G)

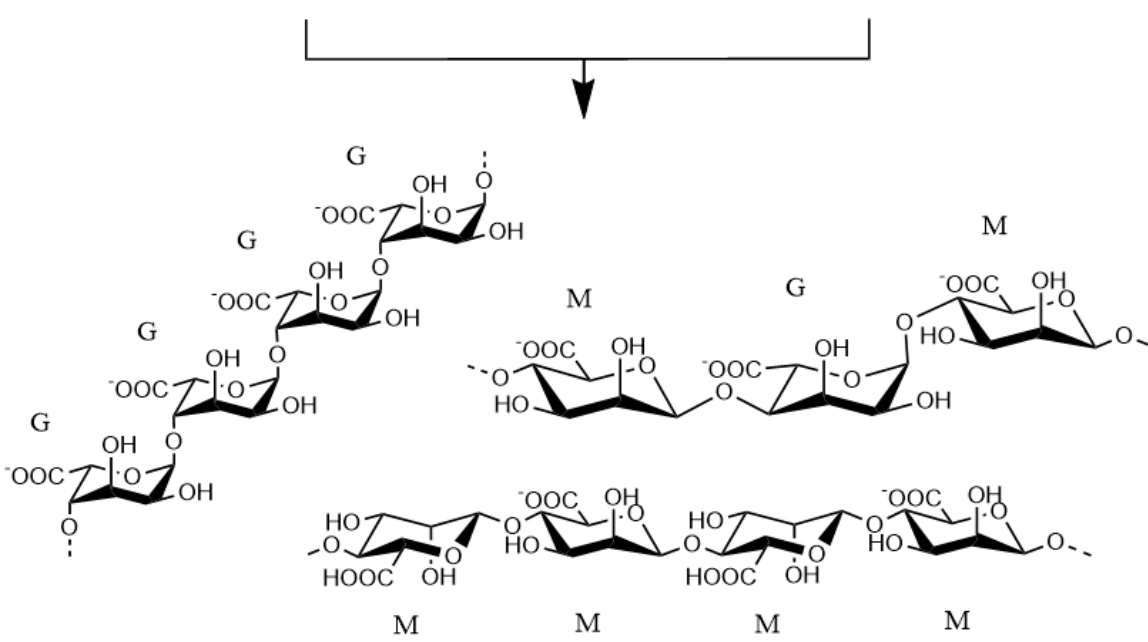

Figure 3. $\beta$-D-mannuronic acid ester (M) and $\alpha$-L-guluronic acid ester $(\mathrm{G})$ are connected by $\beta-1,4$ glycosidic bonds to form poly GG, poly MG, poly MM fragments, and then form alginic acid Copolymer.

\subsection{Sodium Alginate Gels}

Sodium alginate can quickly form a gel under extremely mild conditions, and this gel-forming property is directly related to the $\mathrm{G}$ and $\mathrm{M}$ content. In the presence of $\mathrm{Ca}^{2+}, \mathrm{Sr}^{2+}$ and other cations $[23,24]$, the $\mathrm{Na}^{+}$on the $\mathrm{G}$ unit reacts with the cation and the $\mathrm{G}$ unit accumulates to form a crosslinked network structure, resulting in the formation of hydrogel. The conditions required for this gel formation and 
dissociation process are very mild, which effectively avoid the inactivation of sensitive drugs, proteins, cells and enzymes, resulting in excellent biocompatibility and drug loading properties.

The gel formed from sodium alginate and calcium ions is resistant to freezing and can be recovered using water absorption after drying. The gel strength is directly affected by the concentration of calcium ions and sodium alginate. The higher the concentration, the greater the strength of the gel. The gelation process can be controlled by adjusting the $\mathrm{pH}$, selecting a suitable calcium salt, adding phosphate buffer or chelating agent, or by the gradual release of polyvalent cations or hydrogen ions, or both [25]. The viscosity of sodium alginate is closely related to gel brittleness; the higher the viscosity, the more brittle the gel. By adjusting the ratio of sodium alginate to acid, the rigidity of the gel can be adjusted. Similarly, by controlling the solubility of the calcium salt, the type and rigidity of the gel can be adjusted. A gel can be made quickly using soluble calcium chloride [26]. When calcium dihydrogen phosphate is used, calcium is only released when the temperature rises to between 93 and $107^{\circ} \mathrm{C}$, which delays the gelation time. When the addition of calcium ions reaches $2.3 \%$, a thick gel is obtained; when calcium ion addition is less than $1 \%$, it is a mobile body. When the $\mathrm{pH}$ approaches the isoelectric point of the protein, the protein and sodium alginate form a soluble complex, and the viscosity increases, which inhibits protein precipitation; when the $\mathrm{pH}$ decreases further, the complex precipitates [16].

\subsection{Application of Sodium Alginate-Based Gels in Drug Delivery Systems}

By analyzing the structure and reaction characteristics of alginic acid and its derivatives, it has been found that gels based on sodium alginate have excellent potential for application in various drug delivery systems. The $\mathrm{pH}$-responsive gel property allows adaptation to acid-base changes in the microenvironment, such as in the digestive system. Lin SY et al. [27] prepared a series of calcium alginate particles and dispersed 5-aminosalicylic acid onto the surface of the particles using spraying. Next, different glue coating layers were embedded (Aquacoat and Eudragit L-30D). When the external $\mathrm{pH}$ changes, the calcium alginate particles swell under the action of osmosis, and gradually exceed the loading strength of the gel coating. In this case, the tablets disintegrate and the drug is dispersed allowing slow and controlled release. Similarly, Nilay Kahya et al. prepared sodium alginate ( $\mathrm{NaAlg}$ )/sodium carboxymethyl cellulose $(\mathrm{NaCMC})$ composite hydrogel beads by crosslinking with a barium chloride solution to carry methotrexate [28]. T.S. Anirudhan et al. developed a novel $\mathrm{pH}$-sensitive bioactive amine mesoporous silica-alginate/folic acid conjugated o-carboxymethyl chitosan-gelatin (AMSN-Alg/FA-CMCT-Gel) composite nanogel system, which was used to transport 5-Fluorouracil (5-FU) and didemethoxycurcumin (BDC). The combination of nano-encapsulation and BDC improved the efficiency of 5-FU in the treatment of colorectal cancer [29]. With the development of nano-biomaterials, these properties have been increasingly applied in microstructure technology [16,30-36].

In addition, the temperature responsive characteristics of alginate gels provide numerous possibilities for the use of alginate gels as intelligent drug carriers. Durkut $\mathrm{S}$ et al. developed a thermosensitive poly( $N$-vinylcaprolactam)-grafted aminated alginate (PNVCL-g-Alg- $\mathrm{NH}_{2}$ ), which underwent a phase transition and water absorption expansion at approximately $35{ }^{\circ} \mathrm{C}$, which is suitable for the physiological temperature environment. Furthermore, copolymerization with PNVCL reduces the water absorption of the aminated alginate and improves its thermal stability. In terms of biocompatibility, in vitro cytotoxicity and blood compatibility analyses confirmed that the PNVCL-g-Alg- $\mathrm{NH}_{2}$ scaffolds were not cytotoxic and did not induce hemolysis [37]. Min Liu et al. coupled poly(N-isopropylacrylamide) (PNIPAAm) with sodium alginate to synthesize a thermally responsive copolymer alginate-g-PNIPAAm (Figure 4) [38]. The copolymer was dissolved in water or a phosphate buffered saline solution at room temperature $\left(25^{\circ} \mathrm{C}\right)$. When the temperature rose above the critical micelle temperature, a self-assembled micelle with a low critical micelle concentration was formed, and when the temperature rose to body temperature $\left(37^{\circ} \mathrm{C}\right)$, the copolymer transformed into a thermosensitive hydrogel. To demonstrate a practical application, doxorubicin (DOX) was loaded into the sodium alginate-g-PNIPAAm to construct an injectable thermally-responsive sustained release 
hydrogel. The continuous release of DOX-encapsulated micelles effectively enhanced the DOX uptake of multidrug resistant AT3B-1 cells and was effective at killing cancer cells, demonstrating that drug resistance was overcome.

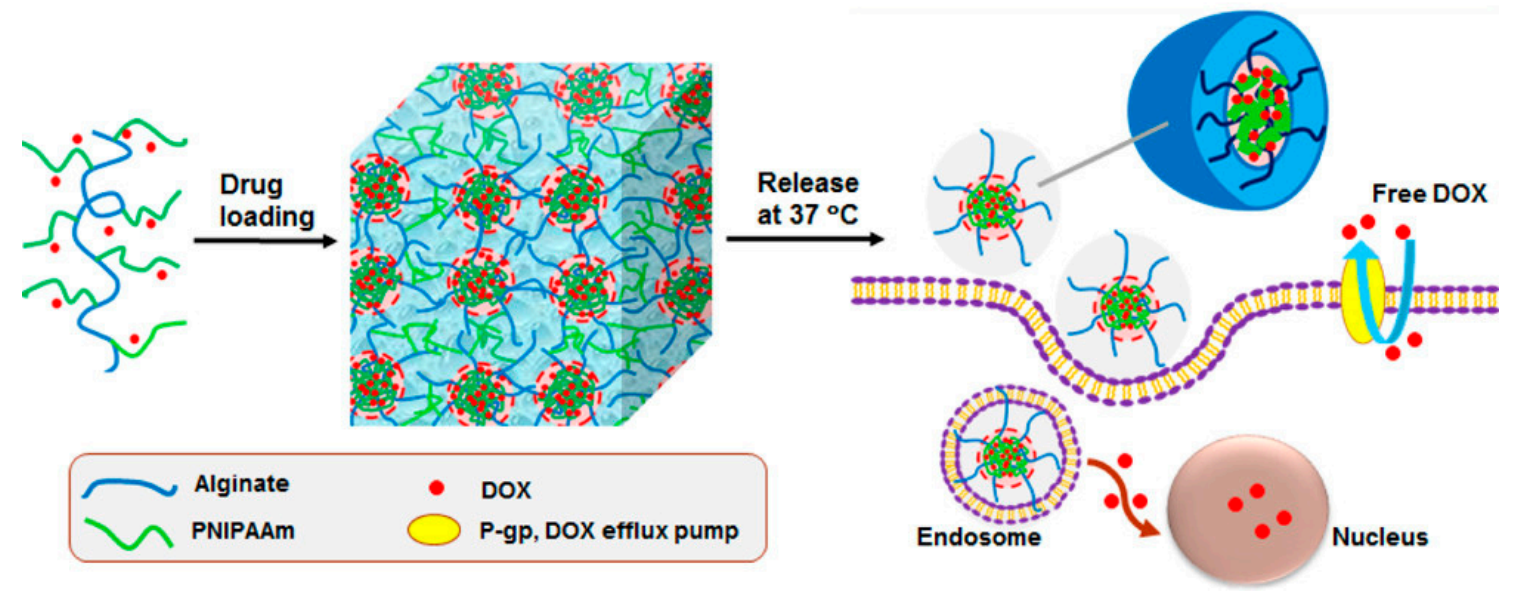

Figure 4. The technology route of thermal response copolymer sodium alginate-g-poly ( $N$-isopropylacrylamide) (alginate-g-PNIPAAm), Reproduced with permission from [38]. ACS Appl. Mater. Interfaces, 2017.

\section{Carrageenan and Its Derivatives}

Carrageenan is a high molecular weight hydrophilic polysaccharide extracted from red algae, Rhodophyta. It is one of the most widely used algin products in industrial applications, along with agar, in the world. It is a translucent sheet or powder with a white to yellowish brown appearance, has a wrinkled surface and is slightly glossy, odorless and tasteless, sticky and slippery. It is often used in the food industry, such as during the manufacture of jelly, ice cream, canned food, etc., and has good water retention, thickening, emulsifying and gelling characteristics, as well as being safe and non-toxic.

\subsection{Structure and Characteristics}

Carrageenan is a linear polysaccharide compound formed from alternating sulfated or non-sulfated galactose units and linked with $\alpha-1,3$ glycosidic bond and $\beta-1,4$-galactose bonds. It can carry a sulfate group on the D-galactose unit C-4' connected at the 1-position and has a molecular weight of more than 200,000. It can be derived from the calcium, potassium, sodium and ammonium salts of the polysaccharides sulfates and composed of various galactose and dehydrated galactose units. In addition, depending on the position at which the semi-ester sulfate group is connected on the galactose unit, it can be divided into seven main types: $K$-carrageenan, l-carrageenan, $\lambda$-carrageenan (Figure 5), $\gamma$-carrageenan, $\nu$-carrageenan, $\xi$-carrageenan and $\mu$-carrageenan [39]. The $\kappa$-type carrageenan forms a brittle gel with potassium ions and forms a soft, elastic gel on interaction with calcium ions; $\lambda$-carrageenan does not form a gel when combined with a salt. Generally, the carrageenan produced from algae is not a pure version of one of the above products, but exists in a mixture.

The sulfate radical on the carrageenan molecule has a strong negative charge and adheres to polycationic macromolecules and amphoteric proteins. Below the isoelectric point, the electrostatic action resulting from a positive and negative charge produces precipitation; above the isoelectric point, the two hold the same charge, and there are polyvalent cations acting as a binding agent with carrageenan to form a hydrophilic colloid; at the isoelectric point, precipitation occurs via the combination of polyvalent cations with carrageenan. These properties are beneficial for the encapsulation and release of proteins, and allow combination with polycations to form new carriers for delivery systems.

Although carrageenan has many natural advantages and has been widely used in many cosmetics and foods without any adverse effects, the subcutaneous administration of carrageenan has resulted in paw edema in mice. Therefore, it is an inflammatory stimulant of the anti-inflammatory experimental 
mouse model, and means there is a risk of immunological complications during systemic administration, which limits its application in drug delivery systems. Fortunately, in recent years, it has been found that the biocompatibility of carrageenan derivatives can be greatly improved using structural modification. Chemically modified carrageenan was reviewed in detail by Zia et al. [40]. It was found that the biofunctional properties of carrageenan depend, to a large extent, on sulfate groups and their substitution. The addition of sulfate groups makes carrageenan possess both biological activity and biocompatibility, making it more suitable for drug delivery. Moreover, carrageenan exhibits additional properties following modification. When studying the rheology of oxidized red algal galactan, Vanina et al. found that agarose and $\mathrm{k}$-carrageenan were oxidized by (2,2,6,6-tetramethylpiperidinyl) oxy (TEMPO) in the presence of $\mathrm{NaOCl}$ and $\mathrm{NaBr}$; the resulting products, which had several oxidation states, were then characterized. These low oxidation state derivatives are sensitive to heat as well as $\mathrm{pH}$ and calcium, similar to natural polysaccharides [41], which results in a corresponding response and release when introduced into complex and changeable microenvironments in the body.

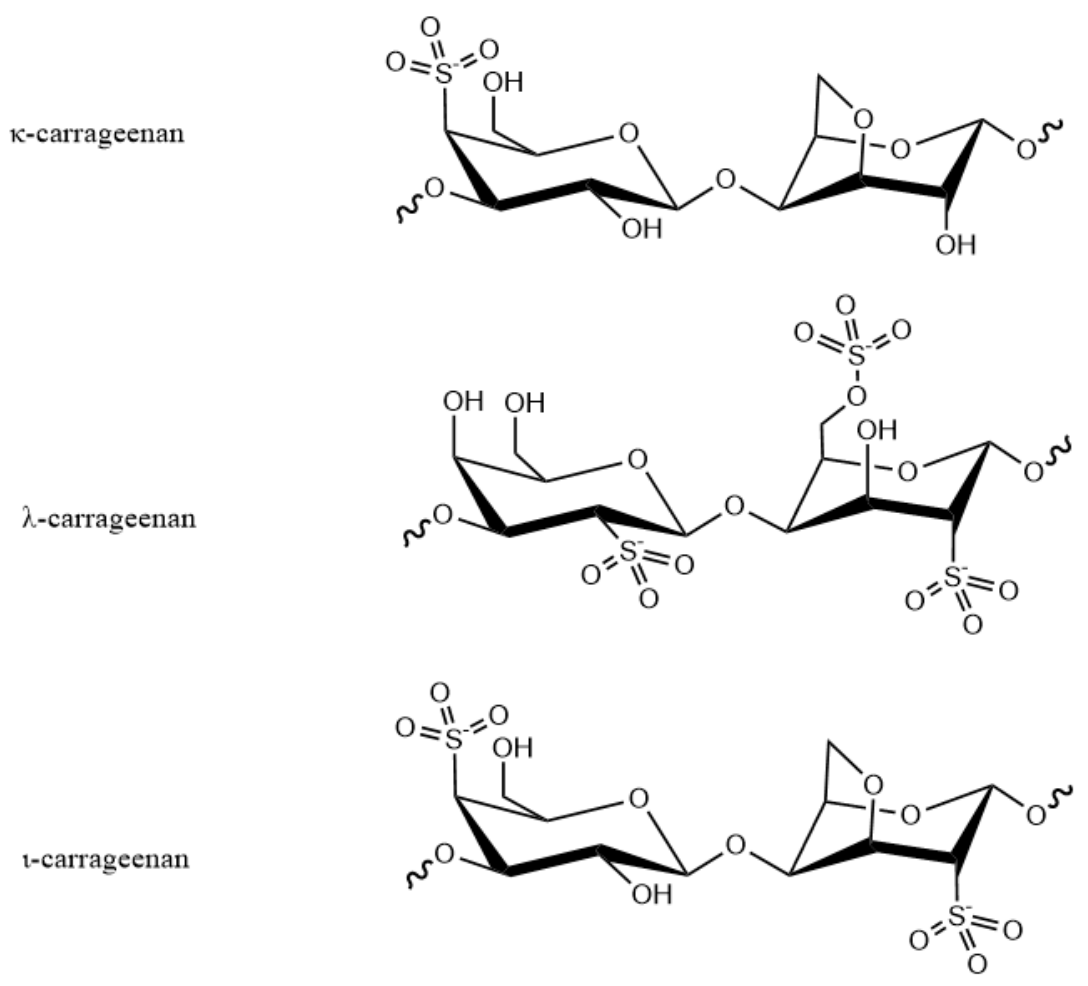

Figure 5. Chemical structures of different types of carrageenans.

\subsection{Carrageenan-Based Gels}

The properties of carrageenan gels are related to its chemical composition, structure and molecular size. The formation of carrageenan gels can be divided into four stages: when dissolved in hot water, the molecule is irregularly curled; when the temperature decreases, the molecule forms a single helix; when the temperature drops further, a double helix is formed between the molecules (a three-dimensional network structure), and solidification begins to occur; when the temperature drops even further, the double helix aggregates to form a gel. The formation of the gel is also affected by the presence of cations, and the existence of $\mathrm{Ca}^{2+}$, and $\mathrm{K}^{+}$further reduces the helix-helix aggregation induced by intermolecular interactions, forming an ordered three-dimensional network [42]. $\kappa$-carrageenan exhibits univalent and divalent cation-dependent gelation behavior. However, in the presence of these cations, $\lambda$-carrageenan does not form a gel, but the viscosity of the solution increases. The absence of a 3,6-anhydro bridge unit in $\lambda$-carrageenan and the inward orientation of the sulfate group at the 2 position prevent crosslinking of the adjacent double helix, thus preventing gel formation [43]. 
The dual response to different ions and temperature means the gel has excellent potential in drug delivery systems.

Further, the gel state of carrageenan is also affected by the acidity and basicity, with viscosity and gel strength lost at $\mathrm{pH} 4.3$ and when heated. This is due to the hydrolysis of carrageenan at low $\mathrm{pH}$, which disconnects the bonds within 3,6-dehydration-D-galactose. The degree of hydrolysis increases at higher temperatures and lower cation concentrations. However, once the temperature of the solution is lower than the gel temperature, potassium ions bind to the sulfate group on carrageenan, which prevents hydrolysis.

\subsection{Application of Carrageenan-Based Gels in Drug Delivery Systems}

Following the development and progress made with respect to carrageenan modification, a number of drug delivery breakthroughs have been achieved. Sato et al. prepared temperature-responsive polysaccharide particles through the formation of an emulsion and the subsequent sol-gel transformation of polysaccharides. It was found that sunken $\mathrm{k}$-carrageenan particles may remain in the alveoli, and were likely to produce significant therapeutic effects in pulmonary administration [44].

Malairaj Sathuvan et al. successfully prepared $\mathrm{pH}$-responsive $\mathrm{k}$-Car-Cur active drug carriers using solvent volatilization and freeze-drying methods. As shown in Figure 6, when adapted to the tumor microenvironment, the drug release was more active when at $\mathrm{pH} 5.0$, and the cumulative release rate reached $78 \%$. When applied in vitro, and compared with free curcumin (CUR), the k-Car-Cur drug-loaded complex induced apoptosis of A549 tumor cells more effectively [45]. Furthermore, Latufa Youssouf et al. used protection/de-protection technology to transplant a polycaprolactone (PCL) chain onto oligo-carrageenan to obtain a polycaprolactone-grafted carrageenan. The amphiphilic polymer formed a spherical nanogel with an average size of $187 \pm 21 \mathrm{~nm}$, which could effectively encapsulate hydrophobic drugs such as curcumin and release them over a period of 24-72 h [46]. Azizi, $\mathrm{S}$ et al. prepared crosslinked carrageenan/silver nanoparticle hydrogel beads using $\mathrm{k}$-carrageenan and biosynthetic silver nanoparticles (Ag-NPs) as the matrix. Compared with a pure $\mathrm{k}$-carrageenan hydrogel, the biological nanocomposite hydrogel exhibited less swelling behavior. It also demonstrated good antibacterial activity against Staphylococcus aureus, methicillin resistant Staphylococcus aureus, Pseudomonas aeruginosa and Escherichia coli, with a maximum inhibitory interval of $11 \mathrm{~mm}$. The cytotoxicity study showed that, at a concentration of less than $1000 \mu \mathrm{g} / \mathrm{mL}$, the non-toxic biological nanocomposite hydrogel had great pharmacological potential [47]. 


\section{cross-linking of Curcumin in K-Carrageenan Beads}

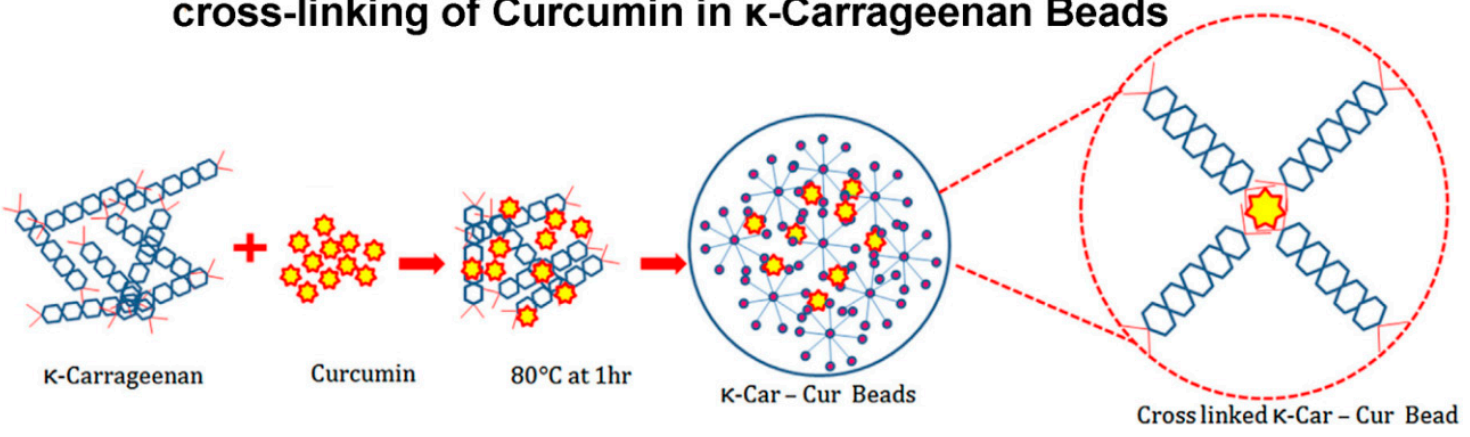

apoptotic activity of $\mathrm{K}$-Car-Cur in A549 cells

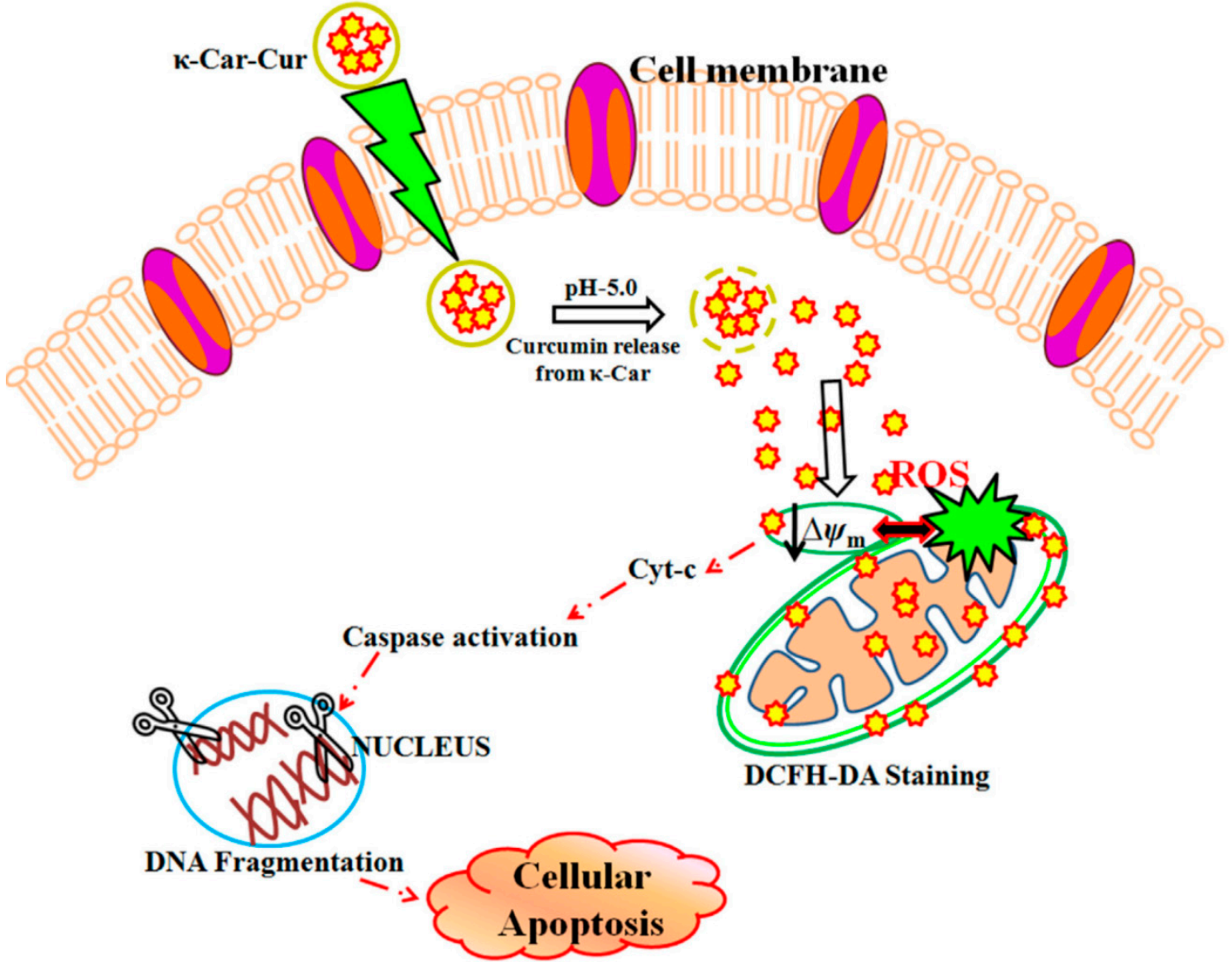

Figure 6. Schematic representation of cross-linking phenomenon of developed k-Car-Cur materials and its mechanism of action. Reproduced with permission from [45]. Carbohydr. Polym, 2017.

\section{Other Seaweed Polysaccharides}

\subsection{Structure and Characteristics of Other Seaweed Polysaccharides}

Many types of seaweed polysaccharide have been shown to exhibit value in terms of their structural and biological properties; these include fucoidan and $\beta$-glucan extracted from Rhodophyta, porphyrin and sulfated galactan extracted from Phaeophycophyta, Ulvans, xylan and mannan extracted from Chlorophyta and GA3P extracted from marine microalgae.

Fucoidans is a polysaccharide from Saccharomyces cerevisiae, is mainly derived from brown algae, and contains fucose and sulfate groups. The analysis of fucoidan isolated from kelp indicated it was composed of $97.8 \%$ fucose and $2.2 \%$ galactose. The analysis of glycosidic bonds showed that 
$(1,3)$ - $\alpha$-1-ethyl fuco-pyranose $(31.9 \%)$ was the main residue, followed by 1,2 -linked $(13.2 \%)$ and 1,4 -linked $(7.7 \%)$ fucose and highly branched $(22.4 \%)$. A large number of studies have shown that fucoidan induces cytotoxicity towards various types of cancer cell, induces apoptosis and inhibits the invasion, metastasis and angiogenesis of cancer cells [48-58]. Damonte et al. discussed the structure of alginate in detail along with its biological functions in the mechanisms of apoptosis, invasion, metastasis, angiogenesis and the growth and signaling of cancer cell growth, which proved the medicinal value of these alginoglycans [59]. Recently, researchers have studied six types of fucoidan (FRF) including FRF F0.7, F1.5 and F2.1, and found they can be used as antioxidants to protect bone tissue from oxidative stress and may represent an adjuvant for the treatment of bone fragility by counteracting oxidation [60].

$\beta$-glucan is a polysaccharide connected by $\beta$-glucose residues through various glycosidic bonds. In previous studies, it was mainly found in oats, barley and yeast and more recently has been found in some brown algae. The formation of a linear polysaccharide chain is obtained via the hydrolysis of kelp protease, and is therefore also known as kelp polysaccharide. Lee et al. [61] described the potential wound healing, immune regulation and anti-tumor activity of kelp polysaccharides. It was reported that kelp polysaccharides have regulatory effects including anti-systemic inflammation via reduction of inflammatory cell recruitment in the liver and reduction of inflammatory mediator expression. Kelp polysaccharides purified from Irish brown seaweed (Laminaria hyperborea) and kelp have significant antioxidant, radical scavenging for 1-diphenyl-2-picrylhydrazine (DPPH) and antibacterial activity [62]. According to Tsiapali et al. [63], Laminaria polysaccharides have strong oxygen free radical absorption abilities, with an EC50 value of $460 \mathrm{mg} / \mathrm{mL}$. It is speculated that the anti-inflammatory effects may be related to the resistance to the oxidation of $\beta(1 \rightarrow 3)$-glucan. Although kelp polysaccharides do not form hydrogels in their natural state, photocrosslinked laminarine chemically modified using glycidyl methacrylate exhibits hydrogel properties as well as the ability to encapsulate human adipose-derived stem cells [64].

Ulvan is an acidic structural polysaccharide, which exists in the cell walls of green algae (Ulva lactuca and Enteromorpha). It is composed mainly of rhamnose 3-sulfate, xylose 2-sulfate, glucuronic acid and iduronic acid, and belongs to a group of highly sulfated polysaccharides. Studies have shown that Ulvan exhibits a variety of therapeutic activities, including antibacterial, immunostimulatory, anti-tumor, antioxidant, anti-hyperlipidemia, antiviral and anticoagulant (Table 1). The polysaccharide chain of Ulvan is unstable and is affected by the growth environment and the extraction methods used. More specifically, temperature and the ionic environment seriously affect the structure and morphology of Ulvan, as well as the properties of its gels. For example, under alkaline conditions, Ulvan forms a gel in the presence of $\mathrm{Ca}^{2+}$ and $\mathrm{B}^{+}$ions, with the existence of divalent cations enhancing the gelation ability, leading to the formation of a thermally reversible gel. As well as being $\mathrm{pH}-$, ion- and temperatureresponsive, the repeating unit within Ulvan has chemical affinity with glycosaminoglycans (such as hyaluronic acid and chondroitin sulfate); therefore, it should also have potential application value in gel drug delivery systems [65].

Table 1. Biological activities of several typical marine polysaccharides [66-86].

\begin{tabular}{ccc}
\hline Polysaccharides & Biological Functions & Ref \\
\hline & Antioxidant & {$[66]$} \\
& Improves the intestinal microbial system & {$[67]$} \\
Reduces the risk of cardiovascular disease & {$[68]$} \\
& Reduces blood cholesterol levels & {$[69]$} \\
& Promotes central nervous system axonal & {$[70,71]$} \\
& regeneration & {$[72-77]$} \\
\hline
\end{tabular}


Table 1. Cont.

\begin{tabular}{ccc}
\hline Polysaccharides & Biological Functions & Ref \\
\hline \multirow{3}{*}{ Fucoidan } & Antioxidant & {$[78]$} \\
& Anticoagulant & {$[79-83]$} \\
& Anti-inflammatory & {$[50,84]$} \\
& Anticancer & {$[59,84,85]$} \\
& Enhances immunity & {$[86]$} \\
\hline \multirow{2}{*}{ Vulcanized } & Enhances immunity & {$[87]$} \\
polysaccharides & Antioxidant & {$[88]$} \\
& Anticancer & {$[89]$} \\
\hline
\end{tabular}

GA3P is composed of the marine microalgae Dinoflagellate gymnodinium SP. The structure of the extracellular polysaccharide is mainly D-galactosome sulfated with L-lactic acid. However, GA3P exhibits strong cytotoxicity regardless of whether lactic acid was present. It can induce apoptosis of human leukemia K562 cells. GA3P is also a strong contact-reactive inhibitor of topoisomerase I and II and the mechanism of its inhibitory effect is similar to that of dextran sulfate. In contrast to camptothecin (CPT) and teniposide (VM-26), the inhibitory effect of GA3P on topoisomerase I and II does not involve the accumulation of the DNA topoisomerase I and II cleavage complex; that is to say, it does not have topoisomerase toxicity, but is a catalytic inhibitor with dual activity. When GA3P was added to a reaction mixture containing CPT or VM-26, it inhibited the stability of the fission complex induced by CPT or VM-26 [90].

The biological and pharmacological activities of several typical marine polysaccharides are shown in Table 1 [66-86].

\subsection{Application of Other Seaweed Polysaccharides Based Gels in Drug Delivery Systems}

In recent years, in addition to alginic acid and carrageenan, the other common seaweed polysaccharides have been industrially produced on a large scale, and many attempts have been made to apply different seaweed polysaccharides in gel drug delivery systems. Chetna Verma et al. prepared cisplatin (CP)-xanthane gum (TG)-lecithin (LC) nanogels via a nano-emulsion method. These nanogels had a polygonal core-shell structure, in which the CP particles were embedded in the TG core of the nanogel and covered in the form of an LC shell. To study the drug release mechanism, different concentrations of CP were added to the nanogel; the results showed that the nanogel achieved sustained drug release (Figure 7) [91]. Khan H, et al. prepared superabsorbent hydrogels (CMA-g-PAm) using anionic, cold water-soluble carboxymethyl agarose (CMA, a seaweed polysaccharide derivative) and polyacrylamide (PAm) through rapid microwave assisted grafting. Then, they prepared an anionic carboxymethyl agarose-responsive intelligent super absorbent hydrogel based on anionic carboxymethyl agarose, which was able to carry and release the anticancer drug DOX in a controlled manner [92]. Feki An et al. prepared a sensitive chitosan-red marine algae composite polysaccharide hydrogel and selected the protein drug insulin as the model drug to test the in vitro release behavior of the hydrogel; the composite was based on blue crab chitosan (Cs) and red marine macroalgae Falkenbergia rufolanosa polysaccharide (FRP). The structure, morphology, thermal and antioxidant properties of the FRP/Cs hydrogels were characterized. The data showed that the addition of FRP enhances water retention, water absorption and texture. In addition, as shown by the swelling ratio test, the hydrogels were sensitive to $\mathrm{pH}$, ionic strength and temperature. In addition, compared with the samples immersed in pH 7.4 PBS, the hydrogel degradation in pH 1.2 phosphate buffered saline was higher. Similarly, the kinetics of insulin release from the FRP/Cs hydrogels indicated higher insulin release in acidic systems. This study demonstrated that the FRP/Cs hydrogels provide a suitable and promising microenvironment for drug delivery [93]. 
(A)

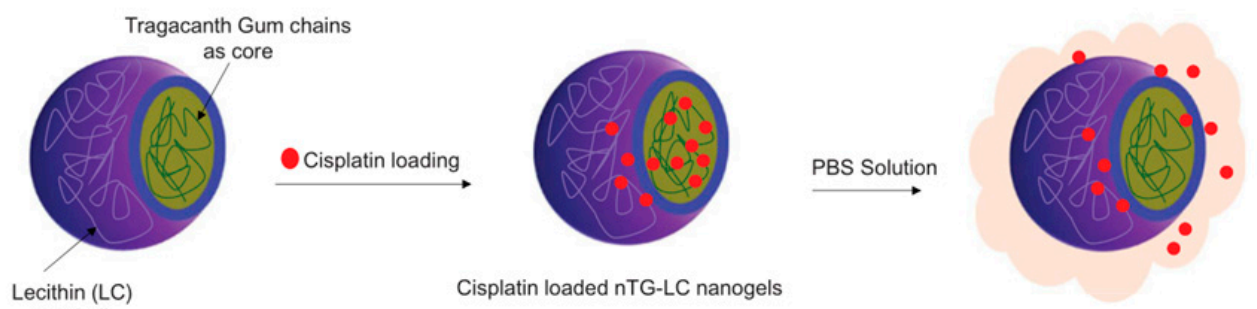

(B)

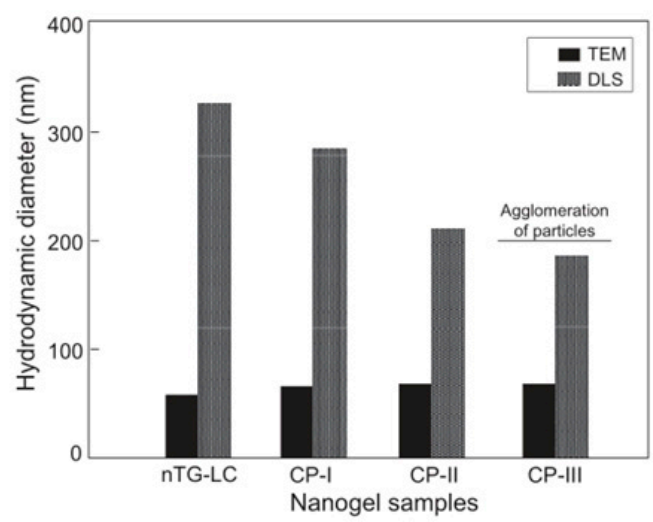

(C)

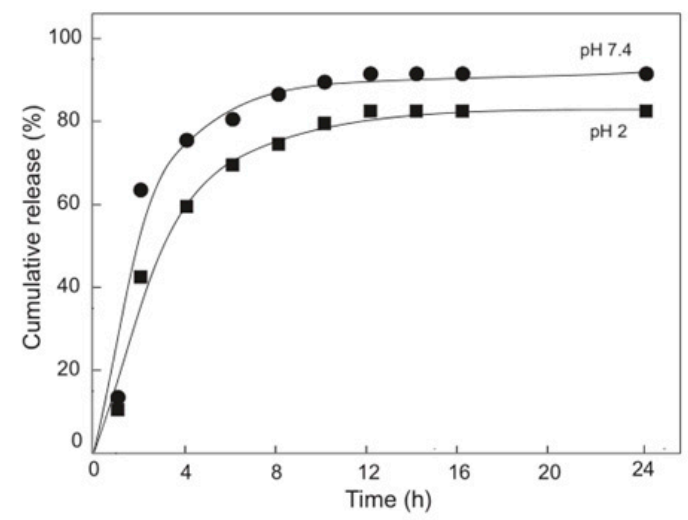

Figure 7. (A) Schematic representation for the designing and development of cisplatin (CP) loaded nTG-LC nanogel and their properties. (B) Hydrodynamic diameter of nTG-LC and varying concentration of CP loaded nTG-LC nanogel. CP-I, 1.2\%, CP-II, 5.2\% and CP-III, 8.5\%. (C) CP release from nTG-LC-CP $(5.2 \% \mathrm{CP})$ in PBS at different $\mathrm{pH} 2$ and 7.4. Reproduced with permission from [91]. Int. J. Polym. Mater, 2020.

\section{Summary and Outlook}

In conclusion, among the wide variety of seaweed polysaccharides, this review is focused on alginic acid and its derivatives in brown algae, carrageenan and its derivatives in red algae, and other kinds of seaweed polysaccharides. Their value is not only limited to anti-inflammatory, bacteriostatic, anticancer and other medicinal values, but also extends to the important potential value in gel drug delivery systems. For example, due to the influence of $\mathrm{Ca}^{2+}$ and $\mathrm{Na}^{+}$concentration within the plasma, the strength of hydrogels prepared by alginic acid and its derivatives extracted from brown algae increases with increasing cation concentration. And a large number of carboxyl groups make it $\mathrm{pH}$-responsive, so the adaptive hydrogel particles can be applied in the controlled release of drugs in gastrointestinal and tumor microenvironments. Similarly, modified carrageenan is temperature- and $\mathrm{pH}$-responsive. These characteristics are across all seaweed polysaccharides, and the gel particles prepared from them exhibit both intelligent responses and biocompatibility. To summarize, ionic conditions, temperature and $\mathrm{pH}$ are the main factors that influence changes in the properties of the gels prepared by seaweed polysaccharides. These properties can be utilized to design gels with intelligent response mechanisms, such as gel films, gel microspheres, nanogels and other intelligent drug delivery gels, and may be applied in the delivery of a wide variety of drugs.

Author Contributions: Literature search, H.Z., X.G. and Q.W.; figures, X.G. and H.Z.; study design, C.C. and X.H.; data collection, C.L. and Q.W.; data analysis, Q.W. and C.L.; data interpretation, X.H. and C.C.; writing, H.Z. and C.C. All authors have read and agreed to the published version of the manuscript.

Funding: This research was funded by National Natural Science Foundation of China (81901896); Tianjin University-Fuzhou University Independent Innovation Fund (TF2020-8).

Conflicts of Interest: No potential conflict of interest to declare. 


\section{References}

1. Muhamad, I.I.; Zulkifli, N.; Selvakumaran, S.A.; Lazim, N.A.M. Bioactive Algal-Derived Polysaccharides: Multi-Functionalization, Therapeutic Potential and Biomedical Applications. Curr. Pharm. Des. 2019, 25, 1147-1162. [CrossRef] [PubMed]

2. Salehi, B.; Sharifi-Rad, J.; Seca, A.M.L.; Pinto, D.; Michalak, I.; Trincone, A.; Mishra, A.P.; Nigam, M.; Zam, W.; Martins, N. Current Trends on Seaweeds: Looking at Chemical Composition, Phytopharmacology, and Cosmetic Applications. Molecules 2019, 24, 4182. [CrossRef] [PubMed]

3. Bouissil, S.; Pierre, G.; Alaoui-Talibi, Z.E.; Michaud, P.; El Modafar, C.; Delattre, C. Applications of Algal Polysaccharides and Derivatives in Therapeutic and Agricultural Fields. Curr. Pharm. Des. 2019, 25, 1187-1199. [CrossRef] [PubMed]

4. Tanna, B.; Mishra, A. Nutraceutical Potential of Seaweed Polysaccharides: Structure, Bioactivity, Safety, and Toxicity. Compr. Rev. Food Sci. Saf. 2019, 18, 817-831. [CrossRef]

5. Bilal, M.; Iqbal, H.M.N. Marine Seaweed Polysaccharides-Based Engineered Cues for the Modern Biomedical Sector. Mar. Drugs 2019, 18, 7. [CrossRef]

6. Priyan Shanura Fernando, I.; Kim, K.N.; Kim, D.; Jeon, Y.J. Algal polysaccharides: Potential bioactive substances for cosmeceutical applications. Crit. Rev. Biotechnol. 2018, 39, 99-113. [CrossRef]

7. Wang, H.M.D.; Chen, C.C.; Huynh, P.; Chang, J.S. Exploring the potential of using algae in cosmetics. Bioresour. Technol. 2015, 184, 355-362. [CrossRef]

8. Berthon, J.Y.; Nachat-Kappes, R.; Bey, M.; Cadoret, J.P.; Renimel, I.; Filaire, E. Marine algae as attractive source to skin care. Free Radic. Res. 2017, 51, 555-567. [CrossRef]

9. Chattopadhyay, N.; Ghosh, T.; Sinha, S.; Chattopadhyay, K.; Karmakar, P.; Ray, B. Polysaccharides from Turbinaria conoides: Structural features and antioxidant capacity. Food Chem. 2010, 118, 823-829. [CrossRef]

10. Kumar, A.; Buia, M.C.; Palumbo, A.; Mohany, M.; Wadaan, M.A.M.; Hozzein, W.N.; Beemster, G.T.S.; AbdElgawad, H. Ocean acidification affects biological activities of seaweeds: A case study of Sargassum vulgare from Ischia volcanic $\mathrm{CO}_{2}$ vents. Environ. Pollut. 2020, 259, 113765. [CrossRef]

11. Abdala Diaz, R.T.; Casas Arrojo, V.; Arrojo Agudo, M.A.; Cardenas, C.; Dobretsov, S.; Figueroa, F.L. Immunomodulatory and Antioxidant Activities of Sulfated Polysaccharides from Laminaria ochroleuca, Porphyra umbilicalis, and Gelidium corneum. Mar. Biotechnol. 2019, 21, 577-587. [CrossRef] [PubMed]

12. Sajadimajd, S.; Momtaz, S.; Haratipour, P.; El-Senduny, F.F.; Panah, A.I.; Navabi, J.; Soheilikhah, Z.; Farzaei, M.H.; Rahimi, R. Molecular Mechanisms Underlying Cancer Preventive and Therapeutic Potential of Algal Polysaccharides. Curr. Pharm. Des. 2019, 25, 1210-1235. [CrossRef] [PubMed]

13. Guo, X.; Wang, Y.; Qin, Y.; Shen, P.; Peng, Q. Structures, properties and application of alginic acid: A review. Int. J. Biol. Macromol. 2020, 162, 618-628. [CrossRef] [PubMed]

14. Sun, Y.; Jing, X.; Ma, X.; Feng, Y.; Hu, H. Versatile Types of Polysaccharide-Based Drug Delivery Systems: From Strategic Design to Cancer Therapy. Int. J. Mol. Sci. 2020, 21, 9159. [CrossRef]

15. Meena, S.; Vidya Kalaivani, M.; Tripathi, A.D.; Ramyaa Lakshmi, T.S. Optimization and characterization of Alginic acid synthesized from a novel strain of Pseudomonas stutzeri. Biotechnol. Rep. 2020, 27, e00517.

16. Barbosa, A.I.; Coutinho, A.J.; Costa Lima, S.A.; Reis, S. Marine Polysaccharides in Pharmaceutical Applications: Fucoidan and Chitosan as Key Players in the Drug Delivery Match Field. Mar. Drugs 2019, 17, 654. [CrossRef]

17. Joshi, S.; Mahadevan, G.; Verma, S.; Valiyaveettil, S. Bioinspired adenine-dopamine immobilized polymer hydrogel adhesives for tissue engineering. Chem. Commun. 2020, 56, 11303-11306. [CrossRef]

18. Vernero, M.; Boano, V.; Ribaldone, D.G.; Pellicano, R.; Astegiano, M. Oral iron supplementation with Feralgine(R) in inflammatory bowel disease: A retrospective observational study. Minerva Gastroenterol. Dietol. 2019, 65, 200-203. [CrossRef]

19. Quadrado, R.F.N.; Fajardo, A.R. Fast decolorization of azo methyl orange via heterogeneous Fenton and Fenton-like reactions using alginate-Fe(2+)/Fe(3+) films as catalysts. Carbohydr. Polym. 2017, 177, 443-450. [CrossRef]

20. Zhang, R.; Zhang, X.; Tang, Y.; Mao, J. Composition, isolation, purification and biological activities of Sargassum fusiforme polysaccharides: A review. Carbohydr. Polym. 2020, 228, 115381. [CrossRef]

21. Sun, H.; Choi, D.; Heo, J.; Jung, S.Y.; Hong, J. Studies on the Drug Loading and Release Profiles of Degradable Chitosan-Based Multilayer Films for Anticancer Treatment. Cancers 2020, 12, 593. [CrossRef] [PubMed] 
22. Zvukova, N.D.; Klimova, T.P.; Ivanov, R.V.; Ryabev, A.N.; Tsiskarashvili, A.V.; Lozinsky, V.I. Cryostructuring of Polymeric Systems. 52. Properties, Microstructure and an Example of a Potential Biomedical Use of the Wide-Pore Alginate Cryostructurates. Gels 2019, 5, 25. [CrossRef] [PubMed]

23. Porter, G.C.; Schwass, D.R.; Tompkins, G.R.; Bobbala, S.K.R.; Medlicott, N.J.; Meledandri, C.J. AgNP/Alginate Nanocomposite hydrogel for antimicrobial and antibiofilm applications. Carbohydr. Polym. 2021, 251, 117017. [CrossRef] [PubMed]

24. Wang, Q.; Zhang, L.; Liu, Y.; Zhang, G.; Zhu, P. Characterization and functional assessment of alginate fibers prepared by metal-calcium ion complex coagulation bath. Carbohydr. Polym. 2020, 232, 115693. [CrossRef]

25. Soulairol, I.; Sanchez-Ballester, N.M.; Aubert, A.; Tarlier, N.; Bataille, B.; Quignard, F.; Sharkawi, T. Evaluation of the super disintegrant functionnalities of alginic acid and calcium alginate for the design of orodispersible mini tablets. Carbohydr. Polym. 2018, 197, 576-585. [CrossRef]

26. Niu, Y.; Xia, Q.; Li, N.; Wang, Z.; Lucy Yu, L. Gelling and bile acid binding properties of gelatin-alginate gels with interpenetrating polymer networks by double cross-linking. Food Chem. 2019, 270, 223-228. [CrossRef]

27. Lin, S.Y.; Ayres, J.W. Calcium Alginate Beads as Core Carriers of 5-Aminosalicylic Acid. Pharm. Res. 1992, 9 , 1128-1131. [CrossRef]

28. Kahya, N.; Golcu, A.; Erim, F.B. Barium ion cross-linked alginate-carboxymethyl cellulose composites for controlled release of anticancer drug methotrexate. J. Drug Deliv. Sci. Technol. 2019, 54, 101324. [CrossRef]

29. Anirudhan, T.S.; Sekhar, V.C.; Nair, S.S. Polyelectrolyte complexes of carboxymethyl chitosan/alginate based drug carrier for targeted and controlled release of dual drug. J. Drug Deliv. Sci. Technol. 2019, 51, 569-582. [CrossRef]

30. Mao, Y.M.; Zhao, M.; Ge, Y.B.; Fan, J. Novel Alginate-Chitosan Composite Microspheres for Implant Delivery of Vancomycin and In Vivo Evaluation. Chem. Biol. Drug Des. 2016, 88, 434-440. [CrossRef]

31. Chen, H.N.; Xing, X.D.; Tan, H.P.; Jia, Y.; Zhou, T.L.; Chen, Y.; Ling, Z.H.; Hu, X.H. Covalently antibacterial alginate-chitosan hydrogel dressing integrated gelatin microspheres containing tetracycline hydrochloride for wound healing. Mater. Sci. Eng. C Mater. 2017, 70, 287-295. [CrossRef] [PubMed]

32. Jin, J.; Ji, Z.X.; Xu, M.; Liu, C.Y.; Ye, X.Q.; Zhang, W.Y.; Li, S.; Wang, D.; Zhang, W.P.; Chen, J.Q.; et al. Microspheres of Carboxymethyl Chitosan, Sodium Alginate, and Collagen as a Hemostatic Agent in Vivo. ACS Biomater. Sci. Eng. 2018, 4, 2541-2551. [CrossRef]

33. Rodness, J.; Mihic, A.; Miyagi, Y.; Wu, J.; Weisel, R.D.; Li, R.K. VEGF-loaded microsphere patch for local protein delivery to the ischemic heart. Acta Biomater. 2016, 45, 169-181. [CrossRef] [PubMed]

34. Fletcher, N.A.; Babcock, L.R.; Murray, E.A.; Krebs, M.D. Controlled delivery of antibodies from injectable hydrogels. Mater. Sci. Eng. C Mater. 2016, 59, 801-806. [CrossRef]

35. Wang, Q.S.; Wang, G.F.; Zhou, J.; Gao, L.N.; Cui, Y.L. Colon targeted oral drug delivery system based on alginate-chitosan microspheres loaded with icariin in the treatment of ulcerative colitis. Int. J. Pharm. 2016, 515, 176-185. [CrossRef]

36. Hazra, M.; Mandal, D.D.; Mandal, T.; Bhuniya, S.; Ghosh, M. Designing polymeric microparticulate drug delivery system for hydrophobic drug quercetin. Saudi Pharm. J. 2015, 23, 429-436. [CrossRef]

37. Durkut, S.; Elcin, Y.M. Synthesis and Characterization of Thermosensitive Poly(N-Vinyl Caprolactam)-Grafted-Aminated Alginate Hydrogels. Macromol. Chem. Phys. 2020, 221, 1900412. [CrossRef]

38. Liu, M.; Song, X.; Wen, Y.; Zhu, J.L.; Li, J. Injectable Thermoresponsive Hydrogel Formed by Alginate-g-Poly(N-isopropylacrylamide) That Releases Doxorubicin-Encapsulated Micelles as a Smart Drug Delivery System. ACS Appl. Mater. Interfaces 2017, 9, 35673-35682. [CrossRef]

39. Torres, M.D.; Florez-Fernandez, N.; Dominguez, H. Integral Utilization of Red Seaweed for Bioactive Production. Mar. Drugs 2019, 17, 314. [CrossRef]

40. Zia, K.M.; Tabasum, S.; Nasif, M.; Sultan, N.; Aslam, N.; Noreen, A.; Zuber, M. A review on synthesis, properties and applications of natural polymer based carrageenan blends and composites. Int. J. Biol. Macromol. 2017, 96, 282-301. [CrossRef]

41. Cosenza, V.A.; Navarro, D.A.; Stortz, C.A.; Rojas, A.M. Rheology of partially and totally oxidized red seaweed galactans. Carbohydr. Polym. 2020, 230, 115653. [CrossRef] [PubMed]

42. Rhein-Knudsen, N.; Ale, M.T.; Meyer, A.S. Seaweed Hydrocolloid Production: An Update on Enzyme Assisted Extraction and Modification Technologies. Mar. Drugs 2015, 13, 3340-3359. [CrossRef]

43. Running, C.A.; Falshaw, R.; Janaswamy, S. Trivalent iron induced gelation in lambda-carrageenan. Carbohydr. Polym. 2012, 87, 2735-2739. [CrossRef] [PubMed] 
44. Sato, T.; Takami, T.; Saito, H.; Murakami, Y. Thermosensitive polysaccharide particles for pulmonary drug delivery. Colloid Surf. A 2019, 580, 580. [CrossRef]

45. Sathuvan, M.; Thangam, R.; Gajendiran, M.; Vivek, R.; Balasubramanian, S.; Nagaraj, S.; Gunasekaran, P.; Madhan, B.; Rengasamy, R. kappa-Carrageenan: An effective drug carrier to deliver curcumin in cancer cells and to induce apoptosis. Carbohydr. Polym. 2017, 160, 184-193. [CrossRef] [PubMed]

46. Youssouf, L.; Bhaw-Luximon, A.; Diotel, N.; Catan, A.; Giraud, P.; Gimie, F.; Koshel, D.; Casale, S.; Benard, S.; Meneyrol, V.; et al. Enhanced effects of curcumin encapsulated in polycaprolactone-grafted oligocarrageenan nanomicelles, a novel nanoparticle drug delivery system. Carbohydr. Polym. 2019, 217, 35-45. [CrossRef] [PubMed]

47. Azizi, S.; Mohamad, R.; Rahim, R.A.; Mohammadinejad, R.; Bin Ariff, A. Hydrogel beads bio-nanocomposite based on Kappa-Carrageenan and green synthesized silver nanoparticles for biomedical applications. Int. J. Biol. Macromol. 2017, 104, 423-431. [CrossRef]

48. Zhang, N.Y.; Gao, L.; Ren, W.H.; Li, S.M.; Zhang, D.M.; Song, X.Q.; Zhao, C.Y.; Zhi, K.Q. Fucoidan affects oral squamous cell carcinoma cell functions in vitro by regulating FLNA-derived circular RNA. Ann. N. Y. Acad. Sci. 2020, 1462, 65-78. [CrossRef]

49. Xue, M.L.; Liang, H.; Ji, X.Q.; Zhou, Z.T.; Liu, Y.; Sun, T.; Zhang, L. Effects of fucoidan on gut flora and tumor prevention in 1,2-dimethylhydrazine-induced colorectal carcinogenesis. J. Nutr. Biochem. 2020, 82, 108396. [CrossRef]

50. Xu, L.; Liu, F.L.; Li, C.; Li, S.X.; Wu, H.; Guo, B.; Gu, J.X.; Wang, L. Fucoidan suppresses the gastric cancer cell malignant phenotype and production of TGF- $\beta 1$ via CLEC-2. Glycobiology 2020, 30, 301-311. [CrossRef]

51. Reyes, M.E.; Riquelme, I.; Salvo, T.; Zanella, L.; Letelier, P.; Brebi, P. Brown Seaweed Fucoidan in Cancer: Implications in Metastasis and Drug Resistance. Mar. Drugs 2020, 18, 232. [CrossRef] [PubMed]

52. Qiu, W.L.; Tseng, A.J.; Hsu, H.Y.; Hsu, W.H.; Lin, Z.H.; Hua, W.J.; Lin, T.Y. Fucoidan increased the sensitivity to gefitinib in lung cancer cells correlates with reduction of TGF $\beta$-mediated Slug expression. Int. J. Biol. Macromol. 2020, 153, 796-805. [CrossRef] [PubMed]

53. Oliveira, C.; Neves, N.M.; Reis, R.L.; Martins, A.; Silva, T.H. A review on fucoidan antitumor strategies: From a biological active agent to a structural component of fucoidan-based systems. Carbohydr. Polym. 2020, 239, 116131. [CrossRef] [PubMed]

54. Hsu, W.J.; Lin, M.H.; Kuo, T.C.; Chou, C.M.; Mi, F.L.; Cheng, C.H.; Lin, C.W. Fucoidan from Laminaria japonica exerts antitumor effects on angiogenesis and micrometastasis in triple-negative breast cancer cells. Int. J. Biol. Macromol. 2020, 149, 600-608. [CrossRef] [PubMed]

55. Gupta, D.; Silva, M.; Radziun, K.; Martinez, D.C.; Hill, C.J.; Marshall, J.; Hearnden, V.; Puertas-Mejia, M.A.; Reilly, G.C. Fucoidan Inhibition of Osteosarcoma Cells is Species and Molecular Weight Dependent. Mar. Drugs 2020, 18, 104. [CrossRef]

56. Etman, S.M.; Elnaggar, Y.S.R.; Abdallah, O.Y. Fucoidan, a natural biopolymer in cancer combating: From edible algae to nanocarrier tailoring. Int. J. Biol. Macromol. 2020, 147, 799-808. [CrossRef]

57. Bai, X.; Wang, Y.; Hu, B.; Cao, Q.; Xing, M.C.; Song, S.L.; Ji, A.G. Fucoidan Induces Apoptosis of HT-29 Cells via the Activation of DR4 and Mitochondrial Pathway. Mar. Drugs 2020, 18, 220. [CrossRef]

58. Bae, H.; Lee, J.Y.; Yang, C.; Song, G.; Lim, W. Fucoidan Derived from Fucus vesiculosus Inhibits the Development of Human Ovarian Cancer via the Disturbance of Calcium Homeostasis, Endoplasmic Reticulum Stress, and Angiogenesis. Mar. Drugs 2020, 18, 45. [CrossRef]

59. Senthilkumar, K.; Manivasagan, P.; Venkatesan, J.; Kim, S.K. Brown seaweed fucoidan: Biological activity and apoptosis, growth signaling mechanism in cancer. Int. J. Biol. Macromol. 2013, 60, 366-374. [CrossRef]

60. Fidelis, G.P.; Silva, C.H.F.; Nobre, L.T.D.B.; Medeiros, V.P.; Rocha, H.A.O.; Costa, L.S. Antioxidant Fucoidans Obtained from Tropical Seaweed Protect Pre-Osteoblastic Cells from Hydrogen Peroxide-Induced Damage. Mar. Drugs 2019, 17, 506. [CrossRef]

61. Lee, J.Y.; Kim, Y.J.; Kim, H.J.; Kim, Y.S.; Park, W. Immunostimulatory Effect of Laminarin on RAW 264.7 Mouse Macrophages. Molecules 2012, 17, 5404-5411. [CrossRef] [PubMed]

62. Kadam, S.U.; O’Donnell, C.P.; Rai, D.K.; Hossain, M.B.; Burgess, C.M.; Walsh, D.; Tiwari, B.K. Laminarin from Irish Brown Seaweeds Ascophyllum nodosum and Laminaria hyperborea: Ultrasound Assisted Extraction, Characterization and Bioactivity. Mar. Drugs 2015, 13, 4270-4280. [CrossRef] [PubMed] 
63. Tsiapali, E.; Whaley, S.; Kalbfleisch, J.; Ensley, H.E.; Browder, I.W.; Williams, D.L. Glucans exhibit weak antioxidant activity, but stimulate macrophage free radical activity. Free Radic. Biol. Med. 2001, 30, $393-402$. [CrossRef]

64. Custodio, C.A.; Reis, R.L.; Mano, J.F. Photo-Cross-Linked Laminarin-Based Hydrogels for Biomedical Applications. Biomacromolecules 2016, 17, 1602-1609. [CrossRef] [PubMed]

65. Tziveleka, L.A.; Ioannou, E.; Roussis, V. Ulvan, a bioactive marine sulphated polysaccharide as a key constituent of hybrid biomaterials: A review. Carbohydr. Polym. 2019, 218, 355-370. [CrossRef] [PubMed]

66. Maity, P.; Sen, I.K.; Maji, P.K.; Paloi, S.; Devi, K.S.P.; Acharya, K.; Maiti, T.K.; Islam, S.S. Structural, immunological, and antioxidant studies of $\beta$-glucan from edible mushroom Entoloma lividoalbum. Carbohydr. Polym. 2015, 123, 350-358. [CrossRef]

67. Shah, A.; Gani, A.; Ahmad, M.; Ashwar, B.A.; Masoodi, F.A. $\beta$-Glucan as an encapsulating agent: Effect on probiotic survival in simulated gastrointestinal tract. Int. J. Biol. Macromol. 2016, 82, 217-222. [CrossRef]

68. Wang, Y.A.; Ames, N.P.; Tun, H.M.; Tosh, S.M.; Jones, P.J.; Khafipour, E. High Molecular Weight Barley $\beta$-Glucan Alters Gut Microbiota Toward Reduced Cardiovascular Disease Risk. Front. Microbiol. 2016, 7, 129. [CrossRef]

69. Wang, Y.N.; Harding, S.V.; Thandapilly, S.J.; Tosh, S.M.; Jones, P.J.H.; Ames, N.P. Barley $\beta$-glucan reduces blood cholesterol levels via interrupting bile acid metabolism. Brit. J. Nutr. 2017, 118, 822-829. [CrossRef]

70. Baldwin, K.T.; Carbajal, K.S.; Segal, B.M.; Giger, R.J. Neuroinflammation triggered by $\beta$-glucan/dectin-1 signaling enables CNS axon regeneration. Proc. Natl. Acad. Sci. USA 2015, 112, 2581-2586. [CrossRef]

71. Elder, M.J.; Webster, S.J.; Chee, R.; Williams, D.L.; Gaston, J.S.H.; Goodall, J.C. $\beta$-glucan Size Controls Dectin-1-Mediated Immune Responses in Human Dendritic Cells by Regulating IL-1 $\beta$ Production. Front. Immunol. 2017, 8, 791. [CrossRef] [PubMed]

72. Novakovic, B.; Habibi, E.; Wang, S.Y.; Arts, R.J.W.; Davar, R.; Megchelenbrink, W.; Kim, B.; Kuznetsova, T.; Kox, M.; Zwaag, J.; et al. $\beta$-Glucan Reverses the Epigenetic State of LPS-Induced Immunological Tolerance. Cell 2016, 167, 1354. [CrossRef] [PubMed]

73. Murri, R.; Camici, M.; Posteraro, B.; Giovannenze, F.; Taccari, F.; Ventura, G.; Scoppettuolo, G.; Sanguinetti, M.; Cauda, R.; Fantoni, M. Performance evaluation of the (1,3)- $\beta$-D-glucan detection assay in non-intensive care unit adult patients. Infect. Drug Resist. 2019, 12, 19-24. [CrossRef] [PubMed]

74. Liao, G.C.; Zhou, Z.F.; Burgula, S.; Liao, J.; Yuan, C.; Wu, Q.Y.; Guo, Z.W. Synthesis and Immunological Studies of Linear Oligosaccharides of $\beta$-Glucan As Antigens for Antifungal Vaccine Development. Bioconjug. Chem. 2015, 26, 466-476. [CrossRef] [PubMed]

75. Fernando, I.P.S.; Sanjeewa, K.K.A.; Lee, H.G.; Kim, H.S.; Vaas, A.P.J.P.; De Silva, H.I.C.; Nanayakkara, C.M.; Abeytunga, D.T.U.; Lee, W.W.; Lee, D.S.; et al. Characterization and cytoprotective properties of Sargassum natans fucoidan against urban aerosol-induced keratinocyte damage. Int. J. Biol. Macromol. 2020, 159, 773-781. [CrossRef] [PubMed]

76. Lee, D.Y.; Nurunnabi, M.; Kang, S.H.; Nafiujjaman, M.; Huh, K.M.; Lee, Y.K.; Kim, Y.C. Oral Gavage Delivery of PR8 Antigen with $\beta$-Glucan-Conjugated GRGDS Carrier to Enhance M-Cell Targeting Ability and Induce Immunity. Biomacromolecules 2017, 18, 1172-1179. [CrossRef]

77. Wang, H.X.; Yang, B.; Wang, Y.L.; Liu, F.; Fernandez-Tejada, A.; Dong, S.W. $\beta$-Glucan as an immune activator and a carrier in the construction of a synthetic MUC1 vaccine. Chem. Commun. 2019, 55, 253-256. [CrossRef]

78. Wang, J.; Zhang, Q.B.; Zhang, Z.S.; Song, H.F.; Li, P.C. Potential antioxidant and anticoagulant capacity of low molecular weight fucoidan fractions extracted from Laminaria japonica. Int. J. Biol. Macromol. 2010, 46, 6-12. [CrossRef]

79. Jin, J.W.; Tang, S.Q.; Rong, M.Z.; Zhang, M.Q. Synergistic effect of dual targeting vaccine adjuvant with aminated $\beta$-glucan and CpG-oligodeoxynucleotides for both humoral and cellular immune responses. Acta Biomater. 2018, 78, 211-223. [CrossRef]

80. Yao, Y.; Zaw, A.M.; Anderson, D.E.J.; Hinds, M.T.; Yim, E.K.F. Fucoidan functionalization on poly(vinyl alcohol) hydrogels for improved endothelialization and hemocompatibility. Biomaterials 2020, 249, 120011. [CrossRef]

81. Abdel-Daim, M.M.; Abushouk, A.I.; Bahbah, E.I.; Bungau, S.G.; Alyousif, M.S.; Aleya, L.; Alkahtani, S. Fucoidan protects against subacute diazinon-induced oxidative damage in cardiac, hepatic, and renal tissues. Environ. Sci. Pollut. Res. 2020, 27, 11554-11564. [CrossRef] 
82. Amin, M.L.; Mawad, D.; Dokos, S.; Koshy, P.; Martens, P.J.; Sorrell, C.C. Immunomodulatory properties of photopolymerizable fucoidan and carrageenans. Carbohydr. Polym. 2020, 230, 115691. [CrossRef] [PubMed]

83. Chale-Dzul, J.; de Vaca, R.P.C.; Quintal-Novelo, C.; Olivera-Castillo, L.; Moo-Puc, R. Hepatoprotective effect of a fucoidan extract from Sargassum fluitans Borgesen against CCl4-induced toxicity in rats. Int. J. Biol. Macromol. 2020, 145, 500-509. [CrossRef] [PubMed]

84. Park, H.B.; Hwang, J.; Lim, S.M.; Zhang, W.; Jin, J.O. Dendritic cell-mediated cancer immunotherapy with Ecklonia cava fucoidan. Int. J. Biol. Macromol. 2020, 159, 941-947. [CrossRef] [PubMed]

85. Sanjeewa, K.K.A.; Lee, J.S.; Kim, W.S.; Jeon, Y.J. The potential of brown-algae polysaccharides for the development of anticancer agents: An update on anticancer effects reported for fucoidan and laminaran. Carbohydr. Polym. 2017, 177, 451-459. [CrossRef] [PubMed]

86. Nagamine, T.; Kadena, K.; Tomori, M.; Nakajima, K.; Iha, M. Activation of NK cells in male cancer survivors by fucoidan extracted from Cladosiphon okamuranus. Mol. Clin. Oncol. 2020, 12, 81-88. [CrossRef] [PubMed]

87. Perez-Recalde, M.; Matulewicz, M.C.; Pujol, C.A.; Carlucci, M.J. In vitro and in vivo immunomodulatory activity of sulfated polysaccharides from red seaweed Nemalion helminthoides. Int. J. Biol. Macromol. 2014, 63, 38-42. [CrossRef]

88. Xian, H.; Jing, H.; Jing, H.; Chen, G.Q.; Cheng, D.F.; Ji, F.; Song, S.H.; Zhang, L. Comparative study of components and anti-oxidative effects between sulfated polysaccharide and its iron complex. Int. J. Biol. Macromol. 2018, 118, 1303-1309. [CrossRef]

89. Lins, K.O.A.L.; Bezerra, D.P.; Alves, A.P.N.N.; Alencar, N.M.N.; Lima, M.W.; Torres, V.M.; Farias, W.R.L.; Pessoa, C.; de Moraes, M.O.; Costa-Lotufo, L.V. Antitumor properties of a sulfated polysaccharide from the red seaweed Champia feldmannii (Diaz-Pifferer). J. Appl. Toxicol. 2009, 29, 20-26. [CrossRef]

90. Umemura, K.; Yanase, K.; Suzuki, M.; Okutani, K.; Yamori, T.; Andoh, T. Inhibition of DNA topoisomerases I and II, and growth inhibition of human cancer cell lines by a marine microalgal polysaccharide. Biochem. Pharmacol. 2003, 66, 481-487. [CrossRef]

91. Verma, C.; Negi, P.; Pathania, D.; Anjum, S.; Gupta, B. Novel Tragacanth Gum-Entrapped lecithin nanogels for anticancer drug delivery. Int. J. Polym. Mater. 2020, 69, 604-609. [CrossRef]

92. Khan, H.; Chaudhary, J.P.; Meena, R. Anionic carboxymethylagarose-based pH-responsive smart superabsorbent hydrogels for controlled release of anticancer drug. Int. J. Biol. Macromol. 2019, 124, 1220-1229. [CrossRef] [PubMed]

93. Feki, A.; Hamdi, M.; Jaballi, I.; Zghal, S.; Nasri, M.; Ben Amara, I. Conception and characterization of a multi-sensitive composite chitosan-red marine alga-polysaccharide hydrogels for insulin controlled-release. Carbohydr. Polym. 2020, 236, 116046. [CrossRef] [PubMed]

Publisher's Note: MDPI stays neutral with regard to jurisdictional claims in published maps and institutional affiliations.

(C) 2020 by the authors. Licensee MDPI, Basel, Switzerland. This article is an open access article distributed under the terms and conditions of the Creative Commons Attribution (CC BY) license (http://creativecommons.org/licenses/by/4.0/). 